Penelitian

\title{
Karakteristik Sitologi Vagina Selama Siklus Estrus dan Gejala Klinis Estrus pada Banteng (Bos javanicus d'Alton 1823)
}

\section{Vaginal Cytology Characteristics During Estrous Cycle and Clinical Sign during estrus in Banteng (Bos javanicus d'Alton 1823)}

\author{
Dedi Rahmat Setiadi ${ }^{1,2 *}$, Muhammad Agil'2, lis Arifiantini ${ }^{2}$, Dondin Sajuthi', Jansen Manansang ${ }^{3}$, \\ Yohana Tri Hastuti ${ }^{3}$, Setyaningsih Rambu Liwa ${ }^{3}$ \\ 'Program Doktor Pascasarjana Institut Pertanian Bogor \\ ${ }^{2}$ Departemen Klinik, Reproduksi dan Patologi, Fakultas Kedokteran Hewan, Institut Pertanian Bogor \\ ${ }^{3}$ Indonesia Safary Park, Cisarua, Bogor \\ *Penulis untuk korespondensi: setiadidvm@gmail.com \\ Diterima 3 Oktober 2020, Disetujui 10 November 2020
}

\begin{abstract}
ABSTRAK
Tujuan dari penelitian ini adalah mempelajari karakteristik gambaran sel-sel ephitelial vagina dan gejala klinis estrus pada banteng. Sebanyak 2 ekor banteng betina yang sehat, sudah dewasa kelamin dan pernah beranak diobservasi secara klinis selama siklus estrus normal dan dilakukan pengambilan sampel ulas vagina. Observasi gejala klinis estrus dan ulas vagina dilakukan tiga kali dalam seminggu dan 5 hari berturut-turut menjelang sampai sesudah estrus. Pemeriksaan fisik ini terdiri atas pemeriksaan simptomatis dengan melihat gejala-gejala yang timbul dari luar seperti gelisah, adanya kebengkakkan, kemerahan, kebasahan pada vulva, naik menaiki, melenguh (meskipun pakan cukup tersedia), keluar lendir jernih transparan. Tingkah laku ketika banteng sedang estrus memperlihatkan perilaku saling naik menaiki sesama banteng dan diam ketika dinaiki, sedangkan tanda klinis lainnya seperti kemerahan, kebengkakan, dan lendir serviks tidak terlihat dengan jelas. Sel-sel ephitel yang diperoleh adalah parabasal, intermediet, superfisial dan kornifikasi. Sel superfisial mendominasi $(50,20 \%)$ pada saat estrus diikuti sel kornifikasi (38,51\%), sel intermediet $(26,82 \%)$ dan sel parabasal $13,44 \%$ selama 3 siklus estrus. Hasil penelitian ini dapat disimpulkan bahwa naik-menaiki sesama banteng pada saat estrus merupakan tanda klinis yang paling jelas terlihat dan teknik sitologi vagina dapat digunakan dalam penentuan siklus estrus banteng.
\end{abstract}

Kata kunci: banteng, estrus, gejala klinis, naik menaiki, sitologi vagina

\begin{abstract}
The research aimed to describe the characteristics of vaginal cytology and during the estrous cycle and to observe the clinical signs of estrus banteng. Two healthy female banteng, sexually mature and had given birth belong to Taman Safari Indonesia were used in this research. Observation of estrus clinical symptoms and vaginal smears is carried out three times a week and 5 consecutive days before until after estrus. Physical examination consists of symptomatic examination by looking for external symptoms such as restlessness, swelling, redness, wetness of the vulva, standing to be mounted, clear transparent mucus. The epithelial cells obtained were parabasal, intermediate, super ficial, and cornified. Superficial cells are very dominant compared to other cells when estrus occurs which is equal to $50.20 \%$ and followed by cornification cells by $38.51 \%$, while other epithelial cells have decreased namely intermediate cells $26.82 \%$ and parabasal cells $13,44 \%$ for 3 estrous cycles. It could be concluded that standing to be mounted by a bull or another female banteng at the time of estrus is the most obvious clinical sign and vaginal cytology techniques can be used in determining the banteng estrous cycle.
\end{abstract}

Keywords: banteng, estrous cycle, clinical sign, standing heat, vaginal cytology 


\section{PENDAHULUAN}

Banteng termasuk spesies yang sudah terancam punah (endangered species), merupakan leluhur sapi sapi domestik di negara-negara Asia Tenggara (Gardner et al., 2016). Banteng dilindungi secara hukum berdasarkan peraturan menteri Lingkungan Hidup dan Kehutanan nomor p.20/menlhk/setjen/ kum.1/6/2018 (KLHK, 2018). International Union for Conservation of Nature (IUCN) menggolongkan banteng dalam red data list sebagai spesies yang terancam punah, namun tidak terdaftar dalam Convention on International Trade in Endangered Species of Wild Fauna and Flora (CITES) (Purwantara et al., 2012; Gardner et al., 2016). Populasi banteng di alam mengalami penurunan di berbagai negara. Penurunan populasi disebabkan oleh perburuan secara illegal, pengrusakan habitat dan penyebaran penyakit yang berasal dari hewan domestik (Purwantara et al., 2012).

Perkembangbiakan banteng secara in situ ataupun ex situ perlu diperhatikan. Perkembangbiakan akan berhasil diterapkan untuk konservasi setelah menguasai aspek-aspek yang berkaitan dengan anatomi dan fisiologi, yaitu karakteristik siklus reproduksi, musim kawin, tingkah laku, dan mekanisme umum lainnya yang mengatur reproduksi (Clay et al., 2010). Kurangnya pengetahuan tentang biologi reproduksi berbagai hewan liar, menyebabkan pengetahuan tentang perilaku reproduksi menjadi terbatas (Lees \& Wilcken, 2009). Pengamatan tersebut sulit untuk dilakukan karena masih kurangnya informasi mengenai pola perilaku hewan liar pada saat estrus terjadi karena informasi tentang perubahan dalam perilaku reproduksi dapat digunakan untuk membantu memonitor siklus hewan liar (Abaigar et al., 2012; Godde et al., 2013).

Siklus estrus dan pengamatan tanda-tanda estrus eksternal dapat digunakan untuk deteksi estrus antara lain sitologi vagina, pengukuran profil hormon, ultrasonografi, atau termografi (Silva et al., 2017). Pengetahuan tersebut sangat penting untuk menentukan waktu yang tepat untuk kawin alam atau melalui inseminasi buatan(IB). Deteksi hewan atau ternak betina saat estrus yang paling mudah dan pasti adalah dengan melihat gejala diam dinaiki (standing heat), yaitu periode penerimaan jantan oleh betina. Indikator ini merupakan in dikator terbaik pada temak yang sedang estrus (DuPonte, 2007).

Sitologi vagina merupakan salah satu teknik dalam menentukan siklus estrus yaitu dengan menganalisis perubahan sel-sel ephitelial vagina. Penelitian mengenai perubahan sitologi vagina selama siklus estrus pada ruminansia besar telah dilaporkan oleh beberapa peneliti. Penelitian sitologi vagina pada sapi aceh telah dilaporkan oleh Siregar et al. (2016), pada kerbau murrah (Joshi et al., 2017) dan sapi bali (Indira et al., 2014; Rahayu et al., 2019). Penelitian mengenai perubahan sitologi vagina pada banteng belum pernah dilakukan, oleh karena itu penelitian ini bertujuan untuk mendapatkan gambaran perubahan sel-sel epitel vagina selama siklus dan saat estrus serta tanda-tanda klinis estrus pada banteng.

\section{BAHAN DAN METODE}

\section{Waktu dan Tempat Penelitian}

Semua prosedur dalam penelitian ini telah memperoleh persetujuan dari Komisi Etik Hewan, IPB atas penggunaan hewan dengan nomor sertifikat: 002/KEH/SKE/I/2020. Penelitian ini dilaksanakan pada bulan Januari sampai dengan Agustus 2018, di Taman Safari Indonesia (TSI) Cisarua, Bogor dan Laboratorium Unit Rehabilitasi Reproduksi (URR), Divisi Reproduksi dan Kebidanan, Departemen Klinik, Reproduksi dan Patologi, Fakultas Kedokteran Hewan, Institut Pertanian Bogor (FKH-IPB).

\section{Bahan dan Alat}

Hewan yang digunakan dalam penelitian ini adalah banteng jawa (Bosjavanicus d'Alton 1823) betina sebanyak 2 ekor, berada di Taman Safari Indonesia (TSI) Cisarua Bogor. Banteng bernama Uchi (9 tahun) dan Andini (13 tahun). Kedua banteng berasal dari Baluran Jawa Timur yang sudah ditangkarkan di Taman Safari Indonesia 2 (TSI 2) Prigen, Pasuruan, Jawa Timur. Kedua banteng sudah dewasa kelamin, dan sudah pernah melahirkan serta dalam kondisi sehat. Banteng tersebut dikandangkan pada malam hari dan dilepaskan pada pagi sampai menjelang sore hari.

\section{Pengamatan Siklus Estrus Hewan Coba}

Pengamatan siklus estrus dilakukan dengan cara pemeriksaan fisik atau klinis banteng tiga kali seminggu selama siklus estrus dan intensif selama lima hari berturut turut menjelang sampai sesudah estrus. Pemeriksaan fisik dilakukan dengan menggunakan panca indera dari perubahanperubahan yang terjadi pada banteng. Pemeriksaan fisik ini terdiri atas pemeriksaan simptomatis dengan melihat gejala-gejala yang timbul dari luar seperti gelisah, adanya kebengkakkan, kemerahan, kebasahan pada vulva, naik menaiki, melenguh 
(meskipun pakan cukup tersedia), keluar lendir jernih transparan. Perubahan pada vulva diberikan skor 1-4 (Tabel 1).

\section{Ulas Vagina}

Banteng betina ditempatkan dalam kandang jepit. Ulas vagina dilakukan menggunakan cotton swab (FL Medical for in Vitro Diagnostic, Sterile, Torreglia, Italy). Cotton swab dibasahi dengan larutan $\mathrm{NaCl}$ fisiologis, kemudian dimasukkan ke bagian dalam vagina sejauh kira-kira $10 \mathrm{~cm}$. Hasil swab setelah itu diulaskan dengan cara diputar searah di atas slide glass. Pengambilan ulas vagina ini dilakukan 3 kali seminggu selama siklus estrus dan intensif 5 hari berturut turut menjelang sampai sesudah estrus.

Ulas vagina yang didapat kemudian dikeringkan di ruang terbuka. Preparat disimpan dalam slide box sampai terkumpul seluruh sampel untuk diwarnai. Slide/preparat direndam dalam larutan Giemsa selama 45 menit (Najamudin et al., 2010), setelah itu dicuci dengan air mengalir (tap water) perlahanlahan kemudian dikeringkan di udara terbuka. Preparat yang sudah kering ditutup dengan cover glass yang dilapisi oleh entellan. Pemeriksaan dilakukan di bawah mikroskop (Olymphus CX 23) dengan pembesaran $10 \times 10$ atau $10 \times 20$. Kriteria fase siklus estrus berdasarkan persentase gambaran perubahan sel ephitelial yang ditemukan saat dilakukan pemeriksaan (Tabel 2).

\section{HASIL}

\section{Gejala Klinis Estrus}

Perilaku diam dinaiki dan naik-menaiki pada banteng yang sedang estrus teramati dengan jelas selama estrus (Gambar 1). Perilaku ini teramati pada saat banteng berada di area pelepasan atau eksibisi. Durasi proses diam dinaiki saat estrus terjadi selama 6-7 detik dengan frekuensi keja dian selama 10-15 kali.

Perubahan gejala klinis pada vulva seperti kemerahan dan kebengkakan tidak tampak dengan jelas, sehingga tidak dapat dibedakan antara banteng estrus dan tidak estrus (Gambar 2). Skoring perubahan vulva berdasarkan skoring yang digunakan adalah 2 yaitu vulva bagian dalam berwarna merah muda, tidak ada vaskularisasi dan permukaan vulva kering (Tabel 1). Lendir estrus teramati dengan baik pada kedua banteng. Lendir estrus teramati pada saat banteng sedang duduk atau saat dilakukan palpasi perektal (Gambar 3).

\section{Pengamatan Siklus Estrus Berdasarkan Karakter- istik Sitologi Vagina}

Pengamatan sel-sel ephitelial vagina selama penelitian menghasilkan 4 jenis sel yaitu parabasal, intermediet, superfisial dan kornifikasi (Gambar 4). Hasil pemeriksaan ulas vagina dari 2 ekor banteng selama 3 siklus estrus dapat dilihat pada Gambar 5 . Gambar 5 memperlihatkan pada fase estrus, kedua

Tabel 1 Skor perubahan vulva pada kondisi estrus

\begin{tabular}{ccl}
\hline No & Skor & \\
\hline 1 & 1 & Pucat, tidak ada vaskularisasi, permukaan vulva kering \\
2 & 2 & Merah muda, tidak ada vaskularisasi, permukaan vulva kering \\
3 & 3 & Merah, terdapat vaskularisasi, permukaan vulva basah \\
4 & 4 & Merah lebih intensif, vaskularisasi lebih kuat, permukaan vulva basah \\
\hline
\end{tabular}

Sumber: Agil (2007); Siregar et al. (2015)

Tabel 2 Kriteria sel-sel ephitel selama siklus estrus

\begin{tabular}{rcl}
\hline No & Sel Ephitel & Bentuk Sel \\
\hline 1 & Intermediet & Memiliki nukleus masih besar dan sitoplasma besar kadang bersudut \\
2 & Superfisial & Memiliki nukleus sangat kecil atau tanpa nukleus, sitoplasma sudut dan terjadi keratinisasi \\
3 & Kornifikasi & Tidak memiliki nukleus dan sitoplasma bersudut \\
4 & Parabasal & Memiliki nukleus yang besar dan sitoplasma bulat \\
\hline
\end{tabular}

Sumber: Miroud \& Noakes (1990) 

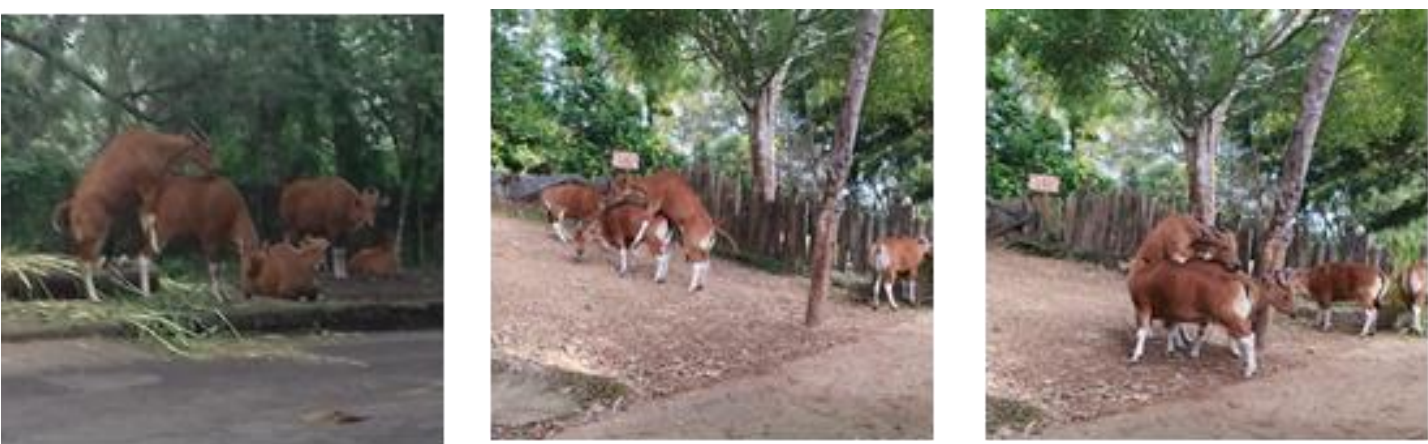

Gambar 1 Posisi ketika menaiki sesama banteng di area pelepasan, diam ketika dinaiki
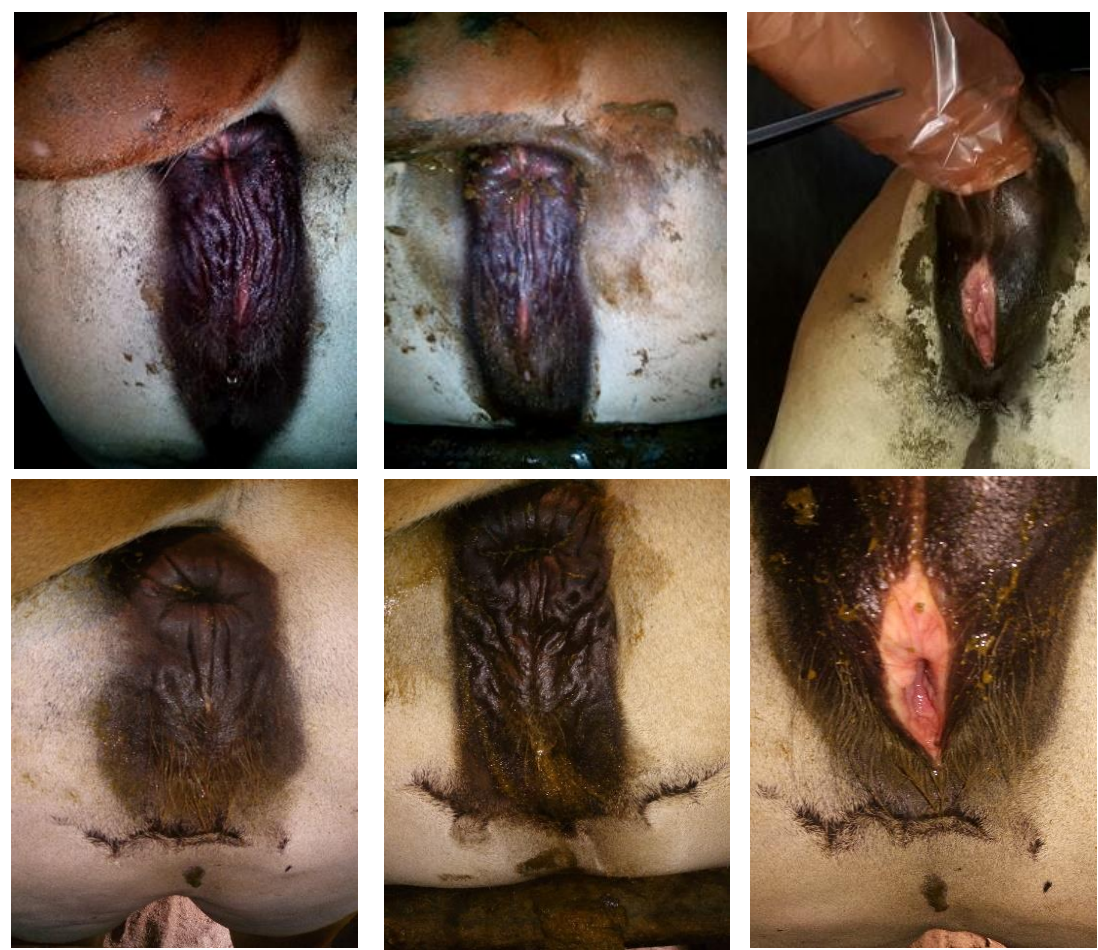

Gambar 2 Banteng dalam kondisi tidak estrus (atas) dan banteng dalam kondisi estrus (bawah)

banteng (Uchi dan Andini) didominasi oleh sel-sel superfisial sebesar $50,20 \%$, diikuti oleh sel kornifikasi sebesar 38,51\%. Sel-sel ephitelial lainnya mengalami penurunan yaitu sel intermediet $26,82 \%$ dan sel parabasal $13,44 \%$. Peningkatan dan penurunan sel-sel epithelial selama siklus estrus ini terjadi selama $22,67 \pm 0,47$ hari, sehingga diperoleh panjang siklus estrus kedua banteng dari hasil pengamatan sitologi vagina adalah 22,2 hari sampai 23,14 hari.

\section{PEMBAHASAN}

Hewan pada saat estrus akibat tingginya konsentrasi hormon estrogen, akan mengalami beberapa perubahan perilaku. Perilaku tersebut antara lain gelisah, keinginan naik-menaiki (O'Connor, 1993; Roelofs et al., 2010; DuPonte, 2007). Vokalisasi khas, nafsu makan menurun (SankarGanesh et al., 2014) dan ekor diangkat ke atas pada saat dinaiki (DuPonte, 2007). Betina estrus umumnya mengalami perubahan pada bagian vulva seperti kebengkakan, kemerahan dan basah, serta keluar lendir transparan, berkelompok (biasanya 3-5 ekor), kotor di bagian pinggul adalah merupakan tanda-tanda sekunder dari seekor hewan yang sedang estrus.

Kedua banteng dalam penelitian ini menunjukkan gejala naik menaiki yang jelas (Gambar 1). Durasi diam dinaiki pada banteng hampir sama dengan sapi, namun frekuensinya lebih sedikit. Sapi yang sedang estrus menurut O'Connor (1993)biasanya diam dinaiki 

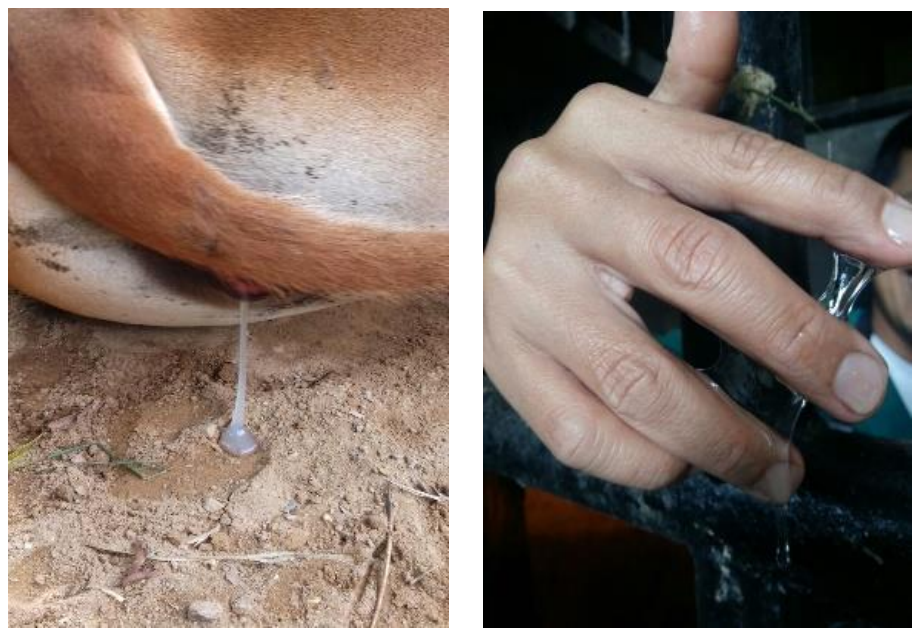

Gambar 3 Lendiryang keluar dari vulva ketika banteng duduk(a), lendir estrus yang keluar saat dipalpasi perektal (b)
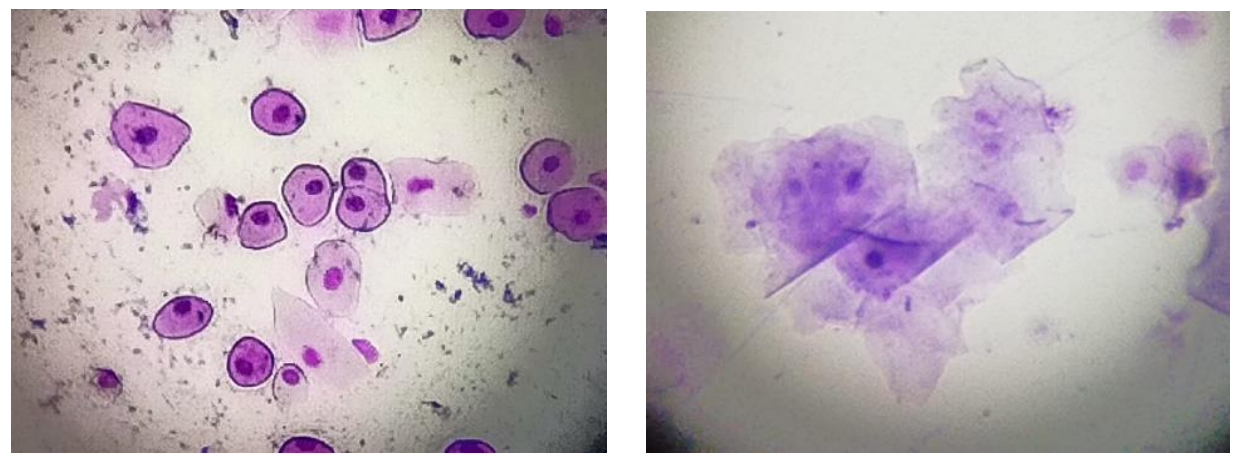

Gambar 4 Pengamatan siklus estrus berdasarkan karakteristik sitologi vagina. Sel parabasal (a), sel intermediet (b), sel superfisial (c) dan sel kornifikasi (d)

sebanyak 20 sampai 55 kali dengan durasi hanya 3-7 detik. Perilaku hewan menaiki dan terutama diam dinaiki sesama kawannya sebenarnya merupakan indikasi yang paling terpercaya bahwa hewan tersebut estrus (Solihati, 2008).

Perubahan vulva pada banteng-banteng dalam penelitian ini tidak terlihat dengan jelas. Kemerahan dan kebengkakan hampir sama dengan kondisi vulva pada saat tidak estrus, sehingga sulit untuk menentukan kondisi estruspada banteng berdasarkan gejala klinis tersebut. Tidak berbedanya perubahan pada vulva ini diduga tidak terjadi peningkatan vaskularisasi yang signifikan di area vulva baikdi labia mayor maupun labia minor, seperti yang terjadi pada temak sapi secara umum. Gejala klinis estrus banteng pada penelitian ini memiliki gejala yang samapada hewan liar lainnya seperti pada gajah (Elephas maximus), tanda-tanda estrus eksternal tidak cukup mencolok dan sulit untuk menilai siklus estrusnya secara fisik (Ghosal et al., 2012).

Penelitian mengenai perubahan sel-sel epitel pada betina yang sedang estrus umum dilakukan pada tikus (Srinivasan et al., 2017), anjing (Schuttle, 2010), dan kucing (Mills et al., 1979, Mattos et al., 2003). Penelitian serupa pada ruminansia juga telah dilaporkan antara lain pada domba (Nurfitriani et al., 2015), pada kambing (Sitaresmi et al., 2018; Leigh et al., 2010). Penelitian pada ruminansia besar telah dilaporkan oleh Miroud \& Noakes (1990) pada sapi perah Mingoas \& Ngayam (2009) pada sapi Bororo zebu serta Siregar et al. (2016) pada sapi aceh. Epitel vagina sensitif terhadap konsentrasi estradiol 17- $\beta$ selama perkembangannya dan reseptor estradiol17$\beta$ terdapat pada jaringan vagina (Bologna, 2001).

Bagian epitel vagina terdiri atas empat jenis sel di mana hampir tiga sel di vagina epitel selalu memiliki kornifikasi, sel parabasal, sel perantara dan superfisial sel. Seluruh tipe sel ditemukan selama siklus estrus. Temuan serupa juga dilaporkan oleh Schuttle (2010) yang menyatakan bahwa sel superfisial dalam ulas vagina secara khusus ditandai untuk kondisi hormon estrogen.

Peningkatan konsentrasi estradiol pada fase proestrus dan estrus berkaitan erat dengan peningkatan jumlah sel superfisial (Siregar et al., 2016). Sel superfisial keluar membran basal dan kemudian 
"Parabasal \& Intermediet Superfisial $<$ Kornifikasi

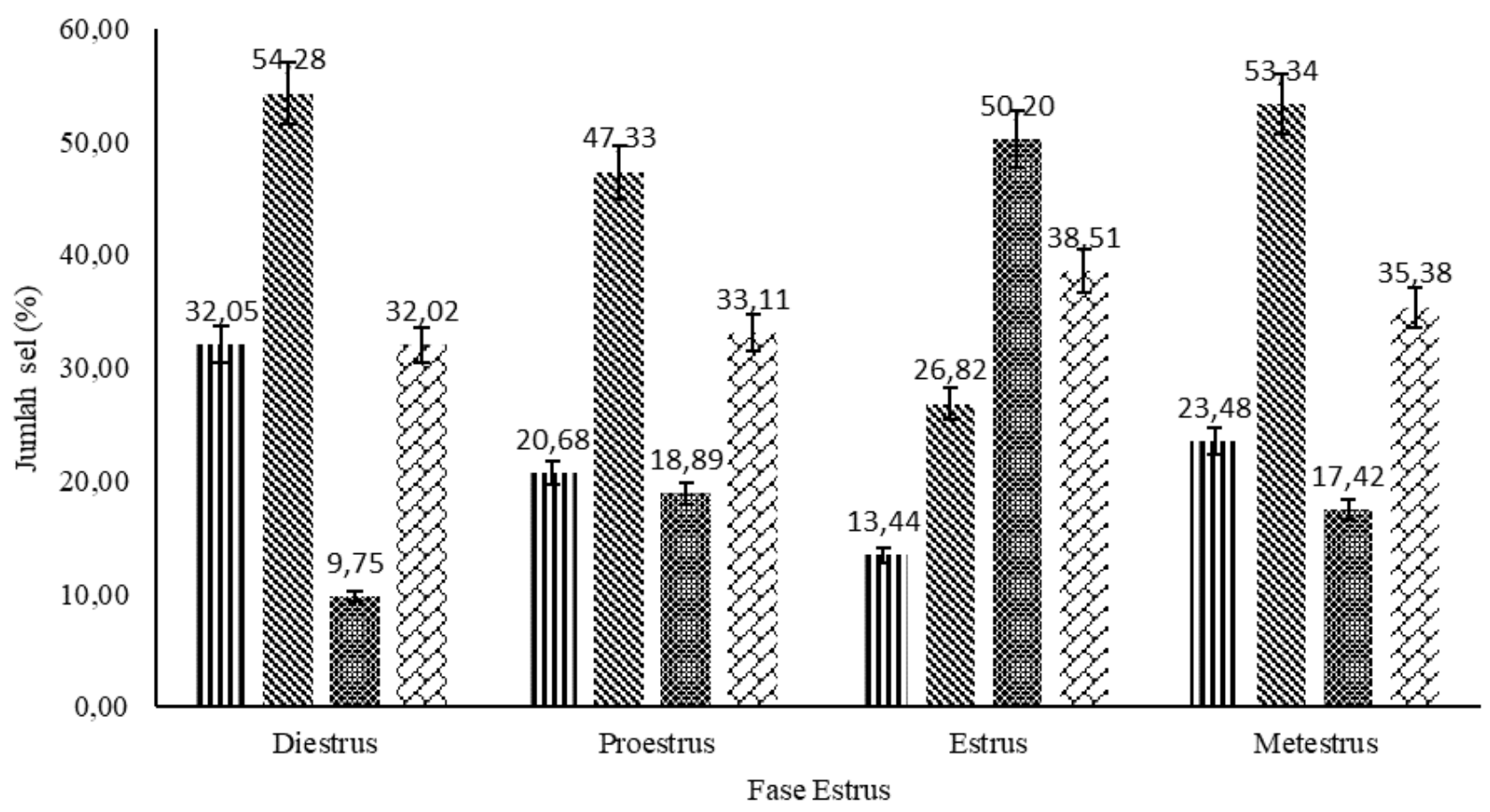

Gambar 5 Persentase sel-sel ephitelial selama 3 siklus kedua banteng (Uchi dan Andini)

berkembang menjadisel lain. Stimulasi estradiol $17-\beta$ mengakibatkan terjadinya perkembangan sel-sel kornifikasi (Indira et al., 2014). Peningkatan sel superfisial ini sama dengan hasil penelitian yang dilakukan oleh Siregar et al. (2016) pada sapi lokal Aceh. Penurunan sel superfisial mulai terjadi pada fase metestrus yaitu pada harike satu sampai hari ke tiga sebesar $17,42 \%$, dilanjutkan pada fase diestrus hari mulai hari ke 4 sampai hari ke 18 sebesar $9,75 \%$. Sel superfial kembali meningkatpada fase proestrus sebesar $18,89 \%$ pada harike 19 sampai hari 21 mencapai puncaknya.

Siregar et al.(2016) lebih lanjut menyatakan bahwa pada sapi aceh sel superfial pada fase diestrus akan mengalami penurunan serta terjadi peningkatan sel intermediet dan parabasal. Sel superfisial mendominasi pada saat sapi dalamkondisi estrus juga telah dilaporkan oleh Baliartiet al. (2018) dan sel intermediet mendominasi pada saat sapi tidak estrus. Peningkatanjumlah sel superfisial ini disebabkan oleh pengaruh hormon estrogen yang meningkatkan sekresi dan akumulasi glikogen dalam jumlah besar yang tersimpan dalam lumen vagina (Hussin, 2010). Sel intermediet dan parabasal lebih mendominasi pada fase lainnya terutama fase diestrus yang disebabkan oleh pengaruh hormon progesteron(Ola et al., 2006).
Penelitian mengenai sitologi vagina pada hewan liar masih terbatas. Snoeck et al. (2011) melaporkan pada Bradypus torquatus yaitu mamalia arboreal dari keluarga Bradypodidae, yang hidup di hutan pantai Atlantik Brasil. Sitologi vagina dari bongo (Tragelaphus eurycerus) Afrika telah dilaporkan oleh Brownscheidle et al., (1979). Kancil, siklus estrusnya juga telah dapat ditentukan dengan melihat gambaran sitologi vagina (Najamudin et al., 2010). Penelitian ini juga mendapatkan bahwa karakteristik sitologi vagina banteng saat estrus setelah dikonfirmasi dengan gejala estrus diam dinaiki didominasi oleh sel superfisial.

Penelitian ini menyimpulkan bahwa sel superfisial mendominasi selama fase estrus pada banteng. Gejala klinis estrus berupa warna mukosa vagina, kebengkakkan dan mucus serviks tidak dapat dijadikan indikator estrus pada banteng. Gejala estrus pada banteng yang paling jelas adalah diam dinaiki.

"Penulis menyatakan tidak ada konflik kepentingan dengan pihak-pihak yang terkait dalam penelitian ini". 


\section{DAFTAR PUSTAKA}

Agil M. 2007. Reproductive Biology of Sumatran Rhinoceros Dicerorhinus sumatrensis (Fischer 1814). Disertasi S3. Sekolah Pascasarjana, Institut Pertanian Bogor. Bogor. p95-96.

Abaigar T, Domenéa MA, Cassinello J. 2012. Characterization of the estrous cycle and reproductive traits of the aoudad (Ammotragus lervia) in captivity. Theriogenology 77: 1759-1766. doi: 10.1016/j.theriogenology. 2011.12.020.

Baliarti E, Priambodo P, Ismaya, Budiyanto A, Yulianto MDE. 2018. Pengamatan Visual Vulva dan Perubahan Behavior Sapi Estrus pada Pemeliharaan di Tingkat Peternak. Prosiding Seminar Teknologi dan Agribisnis Peternakan VI: Pengembangan Sumber Daya Genetik Ternak Lokal Menuju Swasembada Pangan Hewani ASUH, Fakultas Peternakan Universitas Jenderal Soedriman. https://www.researchgate.net/public tion/332138536. Download: October 29, 2020.

Brownscheidle CM, Dresser B, Russell PT. 1979. The estrous cycle of an African Bongo - breeding behavior and cytology of vaginal smears. The Journal of Zoo Animal Medicine 10: 41-49. doi: $10.2307 / 20094414$.

Clay AM, Estes RD, Thompson KV, Wildt DE, Monfort SL. 2010. Endocrine patterns of the estrous cycle and pregnancy of wildebeest in the Serengeti ecosystem. General and Comparative Endocrinology 166: 365-371. doi: 10.1016/j.ygcen. 2009.12.005.

DuPonte, Michael W. 2007. The Basics of Heat (Estrus) Detection in Cattle. Livestock Management. UH, CTAR. 1-3. http://www.ctahr. hawaii.edu/oc/ freepubs/pdf/LM-1. Download: July 13, 2020.

Gardner P, Hedges S, Pudyatmoko S, Gray TNE, Timmins RJ. 2016. Bos javanicus. The IUCN Red List of Threatened Species. http://dx.doi.org/ 10.2305/IUCN.UK.2016-2.RLTS.T2888A46362970. en. Download: October, 192020.

Godde S, Humbert L, Cote SD, Reale D, Whitehead H. 2013. Correcting for the impact of gregariousness in social network analyses. Animal Behaviour 85: 553-558. doi: 10.1016/j. anbehav.2012.12.010.

Ghosal R, Kalaivanan N, Sukumar R, Seshagiri PB. 2012. Assessment of estrus cyclicity in the Asian elephant (Elephas maximus) by measurement of fecal progesterone metabolite $5 \mathrm{a}-\mathrm{P}-3 \mathrm{OH}$, using a non-invasive assay. General and Comparative Endocrinology 175:100-108. doi: 10.1016/j.ygcen. 2011.10.004.
Hussin AM. 2010. The theory of keratinization. Kufa Journal for Veterinary Medicine Sciencist 1(1): 219-229.

Indira PN, Kustono, Ismaya. 2014. The profile of vaginal temperature and cytology of vaginal smear in Bali Cattle during estrus cycle phase. Journal of The Indonesian Tropical Animal Agricultural 39(3): 175-179. doi: 10.14710/jitaa. 39.3.175-179.

Joshi SK, Mohanty TK, Bhakat M, Sathapathy S. 2017. Characteristics of cervical mucus for estrus detection in Murrah Buffaloes (Bubalus bubalis). Journal of Animal Research 7(6): 1129-1134. doi: 10.5958/2277-940X.2017.00169.3.

[KLHK] Kementerian Lingkungan Hidup dan Kehutanan. 2018. Peraturan Menteri Lingkungan Hidup dan Kehutanan Republik Indonesia Nomor P.20/Menlhk/Setjen/Kum.1/6/2018 Tentang Jenis Tumbuhan dan Satwa yang Dilindungi. [Internet]. http://ksdae.menlhk.go.id/assets/news/peraturan /P.20_Jenis_TSL_pdf. Download: June 20, 2020. Lees $\mathrm{CM}^{-}$, Wilcken J. 2009. Sustaining the ark: the challenges faced by zoos in maintaining viable populations. International Zoo Yearbook 43: 6-18. doi: 10.1111/j.1748-1090.2008.00066.x.

Leigh OO, Raheem AK, Olugbuyiro JAO. 2010. Improving the reproductive efficiency of the goat: vaginal cytology and vulvar biometry as predictors of synchronized estrus/breeding time in West African Dwarf Goat. International Journal of Morphololgy 28(3): 923-928. doi: $10.4067 /$ S0717-95022010000300042.

Mattos MRF, Simoes-Mattos L, Machado da Silva LD. 2003. Vaginal cytology in queens with estrus induced with equine chorionic gonadotrophin. Returned Peace Corps Volunteer Collection 98(547): 135-138.

Mills JN, Valli VE, Lumsden JH. 1979. Cyclical changes of vaginal cytology in the cat. The Canadian Veterinary Journal 20: 95-101.

Mingoas JPK, Ngayam LL. 2009. Preliminary findings on vaginal epithelial cells and body temperature changes during oestrous cycle in Bororo zebu cow. International Journal of Biological and Chemical Sciences 3(1): 147-151.

Miroud K, Noakes DE. 1990. Exfoliative vaginal cytology during the oestrous cycle of the cow, after ovariectomy, and after exogenous progesterone and oestradiol-17 $\beta$. British Veterinary Journal 146(5): 387-397. doi: 10.1016/00071935(90)90026-y. 
Najamudin, Rusdin, Sriyanto, Amrozi, Agungpriyono S, Yusuf TL. 2010. Penentuan siklus estrus pada kancil (Tragulusjavanicus) berdasarkan perubahan sitologi vagina. Jurnal Veteriner 11(2): 81-86.

Nurfitriani I, Setiawan R, Soeparna. 2015. Karakteristik vulva dan sitologi sel mucus dari vagina fase estrus pada domba lokal. Beranda 4(3): 1-10.

O'Connor LM. 1993. Heat Detection and Timing of Insemination for Cattle. A Monograph. Agricultural Research and Cooperatives Extension, The Pennsylvania State University. Pennsylvania. p1-17.

Ola SI, Sanni WA, Egbunike G. 2006. Exfoliative vaginal cytology during the oestrous cycle of West African dwarf goats. Reproduction Nutrition Development 46: 87-95. doi: 10.1051 /rnd:2005067.

Purwantara B, Noor RR, Anderson G, Rodriguez Martinez H. 2012. Banteng and bali cattle in Indonesia: status and forecast. Reproduction in Domestic Animals (47): 2-6.

Rahayu J, Salmah S, Yusuf M, Ramadhan B, Sari DK. 2019. The profile and percentage of vaginal epithelial cell numbers during the estrous cycle in bali cattle. IOP Conference Series: Earth and Environmental Science 247: 012006. doi: 10.1088/1755-1315/247/1/012006.

Roelofs J, López-Gatius F, Hunterd RHF, van Eerdenburg FJCM, Hanzen Ch. 2010. When is a cow in estrus? clinical and practical aspects. Theriogenology 74: 327-344. doi: 10.1016/j. theriogenology.2010.02.016.

SankarGanesh D, Ramachandran R, Muniasamy S, Saravanakumar VR, Suriyakala U, Kannan S, Archunan G, Achiraman S. 2014. A correlation of fecal volatiles and steroid hormone profiles with behavioral expression during estrous cycle of goat, Capra hircus. General and Comparative
Endocrinology 206: 178-183. doi: 10.1016/j. ygcen.2014.07.028.

Schuttle AP. 2010. Technique and cytology morphology. Journal Small Animal Practice 18: 301306 doi: 10.1111/j.1748-5827.1967.tbo4554.x.

Silva AR, Moreira N, Pereira AF, Peixoto GCX, Maia KM, Campos LB, Borges AA. 2017. Estrus cycle monitoring in wild mammals: challenges and perspectives. Theriogenology 2017(September): DOI: 10.5772/intechopen.69444.

SiregarTN, Melia J, Rohaya, Thasmi CN, Masyitha D, Wahyuni S, Rosa J, Nurhafni, Panjaitan B, Herrialfian. 2016. Determining proportion of exfoliative vaginal cell during various stages of estrus cycle using vaginal cytology techniques in aceh cattle. Veterinary Medicine International 3976125: 1-5. doi : 10.1155/2016/3976125.

Sitaresmi PI, Astuti PK, Widyobroto BP, Bintara S, Widayati DT. 2018. Exfoliative vaginal cytology and vaginal acidity profile in Ettawa-Saanen grade does. International Journal of Pure and Applied Mathematics 118(24): 1-16.

Snoeck PPN, Cruz ACB, Catenacci LS, Cassano CR. 2011. Vaginal cytology of maned sloth (Bradypus torquatus). Pesquisa Veterinária Brasileira 31(3): 271-275. doi: 10.1590/S0100-736X2011000300015.

Solihati N. 2008. Penggunaan progesteron intravaginal dan kombinasinya dengan PGF2a serta estrogen dalam upaya menimbulkan estrus dan kebuntingan pada sapi perah anestrus. Jurnal Bionatura 10(3): 258-272.

Srinivasan MR, Sabarinathan A, Geetha A, Shalini K, Sowmiya M. 2017. A comparative study on staining techniques for vaginal exfoliative cytology of rat. Journal of Pharmacology \& Clinical Research 3(3): 001-005. doi:10.19080/JPCR.2017.03.555615. 